\title{
Tribute to André Debénath (1st April 1940-2nd June 2016)
}

\author{
Roland Nespoulet $(\mathbb{D}$ - Mohamed Abdeljalil El Hajraoui
}

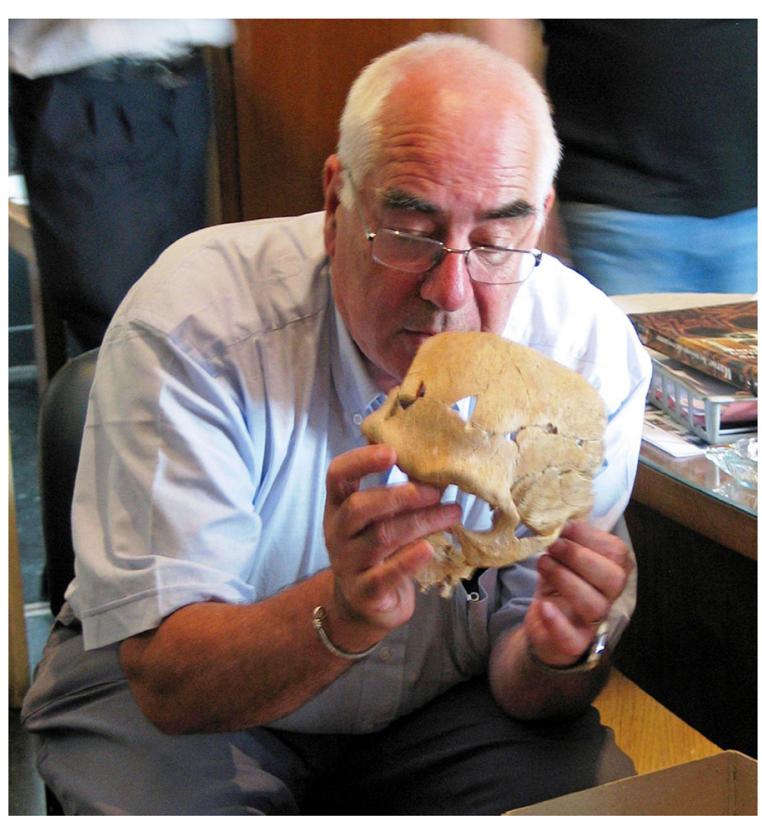

André Debénath with the Aterian skull of Dar-esSoltane 2 (National Archaeological Museum of Rabat, 6/6/2006; photo, R. Nespoulet).

R. Nespoulet $(\bowtie)$

Muséum national d'Histoire naturelle, Département Homme et Environnement, UMR 7194 HNHP, Musée de l'Homme, Paris, France

e-mail: roland.nespoulet@mnhn.fr

M. A. El Hajraoui

Institut National des Sciences de l'Archéologie et du Patrimoine, Rabat, Morocco
The sad loss of Professor André Debénath on 2nd June 2016 aroused great emotion within the community of prehistorians and archaeologists, particularly in France and Morocco.

André was successively Director of Research at UMR 5199 (University of Bordeaux), and then a professor at the University of Perpignan. Since 2006, he held the position of Associate Researcher at the UMR 7194 (Muséum national d'Histoire naturelle in Paris).

André was incredibly proud of his birthplace: Ouezzane, in the Moroccan pre-Rif. And his career as a prehistorian gave him the opportunity to reconnect with his native country when, in his early thirties, he became a member, then the Director, of the French Archaeological Mission in Morocco: a link that remained strong until his death.

His other area of work was in Aquitaine (France), particularly in Charente. He conducted his $\mathrm{PhD}$ research, "Recherches sédimentologiques sur le remplissage des grottes-abris de la Chaise-de-Vouthon (Charente)" - under the direction of François Bordes at the University of Bordeaux - which he defended in 1965, just prior to joining the CNRS. In 1974, he defended his State Thesis in Natural Sciences, entitled "Recherches sur les terrains quaternaires des Charentes et les industries qui leur sont associées," also at the University of Bordeaux.

Above all else, André Debénath was a man of fieldwork. From the Valley of the Tardoire to the Moroccan High Atlas, his entire career was geared to forging international human ties and to sharing his unique and broad experiences. Throughout this career he supervised 
and assisted many French and Moroccan students. Some went on to become researchers in their own right and hold positions of responsibility, but all share the same pride in having had him as their professor. In addition, André also supervised numerous excavations in France and Morocco including: La Chaise-de-Vouthon, La Quina, and Fontéchévade in Charente (France); La Micoque in Dordogne (France); Sidi Abderrhamane, Dar-es-Soltane 2, El Harhoura 1, El Harhoura 2, and El Mnasra (Morocco), where he discovered many human remains belonging to Neanderthals and ancient Homo sapiens.

In the last few years, he had "retired to his Charente lands," as he liked to say. However, this did not limit his involvement in numerous activities, most notably the creation of the museum named Espace d'initiation à $\mathrm{La}$ Préhistoire Charentaise, in Montbron, where he lived with his wife Geneviève, and his role as president of the Historical and Archaeological Society of the Charente.

He also always found time to give lectures, to receive friends, colleagues, and students in the Tardoire Valley, and to write several books: Néandertaliens et CroMagnons (2006), Le Dico de préhistoire (2009), and
Histoire de la Préhistoire en Charentes (2014), not to mention the monograph Préhistoire de la région de Rabat-Témara (El Hajraoui et al. 2012) in which he actively participated.

It is with enormous sadness that we say goodbye to André Debénath. For those of us lucky enough to meet him, we will always carry an imperishable memory of a man of immense culture and exceptional human sensitivity. We have lost not only a great mentor but a wonderful friend.

\section{References}

Debénath, A. (2006). Néandertaliens et Cro-Magnons. Saintes: Le Croît Vif.

Debénath, A. (2009). Le Dico de préhistoire. Saintes: Le Croît Vif.

Debénath, A. (2014). Histoire de la Préhistoire en Charentes. Saintes: Le Croît Vif.

El Hajraoui, M.A., Nespoulet, R., Debénath, A., and Dibble, H. L. (2012). Préhistoire de la Région de Rabat-Témara. Royaume du Maroc Ministère de la Culture: Institut National des Sciences de l'Archéologie et du Patrimoine.' 